\title{
Deoxyribonucleic acid and ribonucleic acid content of human tissues obtained at necropsy
}

\author{
T. F. SLATER, BARBARA SAWYER, AND URSULA STR ̈̈ULI \\ From the Department of Chemical Pathology, University College Hospital \\ Medical School, London
}

SYNOPSIS Values for the deoxyribonucleic acid and ribonucleic acid contents in a considerableir number of human post-mortem tissues are given and briefly discussed.

The deoxyribonucleic acid (D.N.A.) content of a tissue sample is, with certain reservations, a reasonable measure of the number of cells in that sample. This follows from the almost constant D.N.A. content per nucleus (Vendrely, 1955) in many types of cells in somatic tissues. Deviations from this role only occur, for instance, in cells displaying polyploidy or in multinucleate varieties, and in a few other reported instances (Vendrely, 1955) Thus, measurement of D.N.A. affords a simple means of determining the numbers of cells in samples of tissue particularly where, because of large quantities of extracellular material, e.g., milk in samples of mammary gland (Greenbaum and Slater, 1957a), other estimations, such as total protein, bear little relation to the cellular content (Davidson and Leslie, 1950). Measurements of ribonucleic acid (R.N.A.) do not have the same applicability but, as an approximation, the R.N.A. content of a tissue reflects the rate of protein synthesis proceeding in that tissue. For instance, the R.N.A. content of tissues such as liver, lactating mammary gland, and pancreas is much higher than that, say, of skeletal muscle or skin (see Table III).

It was suggested to us by Dr. E. Pochin, Director of the Department of Clinical Research at this Medical School, that it would be of interest to measure the D.N.A. content per gram wet weight of a large number of human tissues. Such values, which, to our knowledge, have not previously been reported, would be proportional in the first approximation to the cell numbers per gram wet weight. The estimated number of cells per organ, i.e., the D.N.A. content per organ, might prove of relevance to the likelihood of late changes developing after irradiation of different organs. In an attempt to provide at least limited data in this respect we have estimated D.N.A.

Received for publication 16 December 1963. (and R.N.A.) in 20 different types of human tissue $\mathbb{\Phi}_{\mathbb{D}}^{\infty}$ obtained after death.

Although only a few cases have been used in this $\stackrel{\mathbb{7}}{3}$ study, due to the problem of obtaining suitable ${ }_{\infty}^{\circ}$ material, it is believed that the data presented will enable a reasonable comparison to be made between 6 the D.N.A. and R.N.A. content of a considerable ${ }^{+}$ number of human tissues. This belief is strengthened by the fact that estimations have been carried out on as many as 18 tissues from the same case.

\section{METHODS}

Tissue samples (obtained at necropsy) were obtained $\overrightarrow{\overrightarrow{7}}$ from cases where the cause of death had involved no 3 infection or long-standing chronic illness. The samples(approximately 1 g.) were placed in bottles containingo ice-cold water for transport to the laboratory and all subsequent procedures were carried out as quickly aso possible. The cold tissue samples were rapidly weighedoand then homogenized in approximately $5 \mathrm{ml}$. cold water. using a Turrax type homogenizer. Each tissue suspension was then transferred to stoppered centrifuging tubes and 3 mixed with an equal volume of cold $10 \%$ trichloroacetic acid. After standing in ice for $20 \mathrm{~min}$. the pellet was centrifuged down and washed twice with approximately $\$$ $5 \mathrm{ml}$. cold $5 \%$ trichloroacetic acid. The pellet was then? suspended in $8 \mathrm{ml} .5 \%$ trichloroacetic acid and warmed at $90^{\circ} \mathrm{C}$. for $20 \mathrm{~min}$. to extract the nucleic acids into solution (Schneider, 1945). After cooling, the protein N residue was centrifuged down and rejected. The super-n natant was filtered and used for the estimation of D.N.A. and R.N.A. Deoxyribonucleic acid was estimated by the method of Burton (1956) using suitable volumes of the supernatants $(0.2$ to $1.0 \mathrm{ml}$.) such that the final extinction at $600 \mathrm{~m} \mu$ was in an accurate region of the spectro? photometer. Ribonucleic acid was measured in the $5 \%$ trichloroacetic acid extracts by the orcinol procedure (Greenbaum and Slater, 1957b).

The results for both D.N.A. and R.N.A. are expressed in terms of phosphorus content (D.N.A.P., R.N.A.P.) as is the normal practice; values given for rat tissues ine 
TABLE I

D.N.A.P. CONTENTS OF HUMAN POST-MORTEM AND RAT TISSUES ${ }^{1}$

\begin{tabular}{|c|c|c|c|c|c|c|c|c|}
\hline \multirow[t]{3}{*}{ Tissue } & \multicolumn{7}{|l|}{ Human } & \multirow[t]{2}{*}{ Rat } \\
\hline & \multicolumn{4}{|l|}{ Male } & \multicolumn{3}{|l|}{ Female } & \\
\hline & $\begin{array}{l}\text { Case A } \\
(\text { Age } 7 I)\end{array}$ & $\begin{array}{l}\text { Case B } \\
\text { (Age 70) }\end{array}$ & $\begin{array}{l}\text { Case C } \\
\text { (Age 60) }\end{array}$ & Mean & $\begin{array}{l}\text { Case D } \\
\text { (Age 18) }\end{array}$ & $\begin{array}{l}\text { Case E } \\
\text { (Age 7I) }\end{array}$ & Mean & \\
\hline Liver & 12.9 & $7 \cdot 7$ & - & $10 \cdot 3$ & - & 9.9 & - & 18.5 \\
\hline Kidney & $11 \cdot 8$ & 11.9 & - & $11 \cdot 8$ & - & $10 \cdot 7$ & - & - \\
\hline Spleen & $22 \cdot 7$ & $38 \cdot 3$ & - & $30 \cdot 5$ & - & $33 \cdot 1$ & - & - \\
\hline Brain & $3 \cdot 1$ & $1 \cdot 2$ & - & $2 \cdot 2$ & - & $2 \cdot 0$ & - & - \\
\hline Adrenal & 8.9 & $3 \cdot 5$ & - & $6 \cdot 2$ & - & 6.6 & - & - \\
\hline Pancreas & $24 \cdot 2$ & $12 \cdot 9$ & $17 \cdot 6$ & $18 \cdot 2$ & $22 \cdot 6$ & $13 \cdot 0$ & $17 \cdot 8$ & $31 \cdot 5$ \\
\hline Thyroid & $16 \cdot 3$ & $5 \cdot 8$ & $9 \cdot 4$ & 10.5 & 11.8 & $6 \cdot 3$ & $9 \cdot 0$ & $36 \cdot 5$ \\
\hline Ovary & - & - & - & - & $25 \cdot 3$ & - & - & $38 \cdot 6$ \\
\hline Prostate & - & $7 \cdot 7$ & $8 \cdot 6$ & $8 \cdot 1$ & - & - & - & $28 \cdot 7$ \\
\hline Testis & - & 13.5 & $17 \cdot 0$ & $15 \cdot 3$ & - & - & - & $19 \cdot 6$ \\
\hline Uterus & - & - & - & - & - & - & - & $28 \cdot 4$ \\
\hline Lung & $14 \cdot 3$ & $9 \cdot 2$ & - & $11 \cdot 7$ & - & $8 \cdot 4$ & - & $45 \cdot 5$ \\
\hline Adipose & 0.6 & 1.0 & - & 0.8 & 0.5 & $\cdot 7$ & 0.6 & - \\
\hline Red marrow & $10 \cdot 1$ & $10 \cdot 9$ & - & $10 \cdot 5$ & - & $13 \cdot 8$ & - & - \\
\hline Skin & $1 \cdot 1$ & $2 \cdot 4$ & 3.4 & $2 \cdot 3$ & 3.7 & - & - & - \\
\hline Small intestine & $19 \cdot 1$ & 17.9 & $15 \cdot 0$ & $17 \cdot 3$ & $11 \cdot 4$ & - & - & $41 \cdot 3$ \\
\hline Large intestine & 6.4 & $9 \cdot 4$ & 6.9 & $7 \cdot 6$ & 4.9 & - & - & - \\
\hline Stomach wall & $11 \cdot 0$ & $11 \cdot 1$ & - & 11.0 & $22 \cdot 5$ & $7 \cdot 5$ & - & - \\
\hline Lymph node & $42 \cdot 1$ & $30 \cdot 3$ & $32 \cdot 7$ & $35 \cdot 1$ & 54.5 & $27 \cdot 2$ & - & - \\
\hline Skeletal muscle & 1.8 & 1.8 & $2 \cdot 2$ & 1.9 & 2.0 & 1.9 & 2.0 & 4.9 \\
\hline
\end{tabular}

${ }^{1}$ Values are given as $\mathrm{mg} . / 100 \mathrm{~g}$. wet wt. tissue.

Table I for comparison were obtained by identical procedures to those outlined for the human postmortem samples.

\section{RESULTS}

Table I shows the results obtained for the D.N.A.P. content of a variety of human and rat tissues. It can be seen that on a mg./100 $\mathrm{g}$. wet weight basis the human samples fall roughly into three groups: 1 D.N.A.P. content high (over $25 \mathrm{mg}$./100 g. wet wt.) in spleen, lymph node, ovary; 2 D.N.A.P. content medium (10-20 mg./100 g. wet wt.) in liver, kidney, pancreas, thyroid, testis, lung, red marrow, small intestine, stomach wall; 3 D.N.A.P. content low (less than $8 \mathrm{mg} . / 100 \mathrm{~g}$. wet wt.) in brain, adrenal, prostate, adipose, skin, large intestine, and skeletal muscle. The range covered by the values in the various tissues examined is large, the difference being 40-fold between the mean values for male adipose tissue and lymph node. Values obtained for the rat show little comparison with the human results. The rat D.N.A.P. content is in every case higher, and sometimes, much higher, than the corresponding human tissue. Using mean weights for each organ (Spector, 1956), the approximate D.N.A.P. content per whole organ can be calculated (Table II). With this method of expressing the results it can be seen that the liver and lungs have much higher D.N.A.P. contents that any of the other tissues examined. Tissues with an intermediate D.N.A.P. content are kidney, spleen, brain, and

\section{TABLE II}

D.N.A.P. CONTENT OF VARIOUS HUMAN POST-MORTEM TISSUES ${ }^{1}$

Tissue Mean Weight of Organ $\begin{aligned} & \text { D.N.A.P. (mg./total } \\ & \text { organ wt.) }\end{aligned}$

\begin{tabular}{lrc}
\hline Liver & $1,838(a)$ & 186.5 \\
Kidney & $313(\mathrm{a})$ & 36.8 \\
Spleen & $204(\mathrm{a})$ & 62.0 \\
Brain & $1,355(\mathrm{a})$ & 29.8 \\
Adrenal & $14(\mathrm{a})$ & 0.86 \\
Pancreas & $85(\mathrm{~b})$ & 15.5 \\
Lung & $953(\mathrm{a})$ & 112.0 \\
Thyroid & $25(\mathrm{a})$ & 2.6 \\
Prostate & $17(\mathrm{a})$ & 1.38 \\
Testis & $28(\mathrm{a})$ & 4.28 \\
Ovary & $10(\mathrm{c})$ & 2.53
\end{tabular}

${ }^{1}$ The D.N.A.P. contents $/ 100 \mathrm{~g}$. wet weight tissue used in this calculation are taken from the mean values in Table I. The weights for different organs were obtained from Spector (1956) for $(a)$ males, 20-30 yr. old, body wt. approximately $71 \mathrm{~kg}$., (b) males, 16-17 yr. old, body wt. $62 \mathrm{~kg}$., and (c) females, 20-30 yr. old, body wt. $56 \mathrm{~kg}$.

perhaps pancreas; the other tissues have a total D.N.A.P. content of less than $3 \%$ of the liver value.

Table III shows the results obtained for ribonucleic acid phosphorus content. The results are more variable from case to case than were found for deoxyribonucleic acid phosphorus. This variability could represent the differences in secretory activity of the different tissues since, with one exception, all of the cadavers used were old and presumably some variable degree of atrophy was present.

Although these estimations have been performed on a limited number of cases, and although sampling errors resulting from using relatively small amounts 
TABLE III

R.N.A.P. CONTENT OF VARIOUS HUMAN POST-MORTEM AND RAT TISSUES ${ }^{1}$

Tissue

Human

Rat

Pancreas

\begin{tabular}{|c|c|}
\hline \multicolumn{2}{|l|}{ Male } \\
\hline Case $A$ & Case B \\
\hline $80 \cdot 0$ & $18 \cdot 2$ \\
\hline 15.8 & 9.5 \\
\hline $16 \cdot 3$ & 15.0 \\
\hline 6.5 & 9.7 \\
\hline $9 \cdot 1$ & $18 \cdot 6$ \\
\hline $26 \cdot 3$ & 16.2 \\
\hline 3.75 & 4.7 \\
\hline $2 \cdot 1$ & 3.7 \\
\hline- & - \\
\hline- & 7.2 \\
\hline- & $10 \cdot 0$ \\
\hline .52 & 1.02 \\
\hline 31.0 & $28 \cdot 3$ \\
\hline $6 \cdot 2$ & $7 \cdot 6$ \\
\hline $14 \cdot 4$ & $15 \cdot 3$ \\
\hline 14.4 & 22.7 \\
\hline 12.6 & 6.65 \\
\hline 9.7 & 6.5 \\
\hline $6 \cdot 3$ & 2.7 \\
\hline
\end{tabular}

Pancreas

Thyroid

Small intestine

Large intestine

Stomach wall

Lymph node

Skeletal muscle

Skin

Ovary

Testis

Prostate

Adipose

Liver

Red marrow

Kidney

Spleen

Lung

Adrenal

Brain

Adrenal $6 \cdot 3$

${ }^{1}$ Values are given as $\mathrm{mg} . / 100 \mathrm{~g}$. wet wt. tissue and the method of estimation used was that of Greenbaum and Slater (1957b).

of tissue were undoubtedly present, it is believed that the values in Tables I-III give a reasonably close estimate of the nucleic acid contents of 20 human tissues. As such it is hoped that they may prove of interest.

We are indebted to Drs. J. F. Smith and P. M. Sutton for providing the post-mortem tissue samples and to Dr. E. Pochin for stimulating our interest in this work.
REFERENCES

Burton, K. (1956). Biochem. J., 62, 315.

Davidson, J. N., and Leslie, I. (1950). Nature (Lond.), 165, 49.

Greenbaum, A. L., and Slater, T. F. (1957a). Biochem. J., 66, 148. - - (1957b). Ibid., 66, 155.

Schneider, W. C. (1945). J. biol. Chem., 161, 293.

Spector, W. S. (1956). In Handbook of Biological Data, edited by W. S. Spector, p. 162. Saunders, Philadelphia.

Vendrely, R. (1955). In The Nucleic Acids, vol. 2, edited by E. Chargaff and J. N. Davidson, p. 155. Academic Press, New York. 